This is an electronic reprint of the original article. This reprint may differ from the original in pagination and typographic detail.

Author(s): Kontinen, Tanja; Ojala, Arto

Title: Internationalization pathways of family SMEs: psychic distance as a focal point

Year: $\quad 2010$

Version:

Please cite the original version:

Kontinen, T. \& Ojala, A. (2010). Internationalization pathways of family SMEs: psychic distance as a focal point. Journal of Small Business and Enterprise Development, 17 (3), 437-454.

All material supplied via JYX is protected by copyright and other intellectual property rights, and duplication or sale of all or part of any of the repository collections is not permitted, except that material may be duplicated by you for your research use or educational purposes in electronic or print form. You must obtain permission for any other use. Electronic or print copies may not be offered, whether for sale or otherwise to anyone who is not an authorised user. 


\title{
Internationalization pathways of family SMEs: Psychic distance as a focal point
}

\author{
Tanja Kontinen and Arto Ojala, University of Jyväskylä
}

\begin{abstract}
Purpose - The purpose of this research is to investigate how psychic distance affects the internationalization process, foreign market entry (FME), and entry mode choice of Finnish small and medium-sized family enterprises (family SMEs) operating in France.

Design/methodology/approach - This paper reports findings from an in-depth case study covering four Finnish manufacturing family SMEs operating in the French market. The data were analyzed using the Uppsala model and distance-creating and distancebridging factors encountered in the FME to France.

Findings - The findings revealed that the family SMEs mainly followed a sequential process and favored indirect entry modes before entering the French market. The French market was experienced psychically distant, but the case firms were able to overcome the distance by using different distance-bridging factors. Based on the findings, it can be argued that psychic distance has an especially important role in the internationalization and FME of family SMEs, mainly because of their general cautiousness caused by family presence.
\end{abstract}

Research limitations/implications - Although the case study method made it possible to acquire detailed knowledge about the firms' internationalization, the findings can be generalized only to some extent.

Practical implications - Managers of family SMEs and family members should be provided with the capacity to overcome distance-creating factors, they might encounter in their FME. The decision to internationalize is a strategic change that will most probably change the historical harmony of the firm.

Originality/value - Prior research has mainly focused only on general internationalization pathways of family SMEs. In addition and contrast to the previous studies, this paper investigates the role of perceived psychic distance in family SMEs' FME and entry mode choice in a certain target market.

Keywords family firms, small- and medium-sized firms, internationalization, foreign market entry, psychic distance, Finland, France

Paper type Research paper 


\section{Introduction}

Family owned and managed firms, most of which are small or medium of their size, continue to dominate the global economy and many of them outperform their nonfamily counterparts (Miller \& Breton-Miller, 2006). As family business (FB) research is rather recent, there are many areas to be covered in order to understand how family ownership and presence in family businesses affect their business activities. Although FBs have traditionally been domestic firms, many of them are increasingly searching for growth opportunities in foreign markets (Claver, Rienda \& Quer, 2007; Fernandez \& Nieto, 2005; Zahra, 2003). Consequently, internationalization of FBs has recently emerged as an important research stream to understand the interplay between the nature of FB and their internationalization behavior (Claver et al., 2007; Graves \& Thomas, 2008).

As earlier studies have indicated that the internationalization process of family SMEs is rather slow and risk averse, they more likely internationalize their operations to nearby countries sharing similar business environments (Claver et al., 2007; Harris, Martinez \& Ward, 1994). This kind of internationalization is related to the Uppsala internationalization model (Johanson \& Wiedersheim-Paul, 1975; Johanson \& Vahlne, 1977) that describes firms' internationalization as a step-wise process. In the model, firms favor nearby countries within a low psychical distance in the beginning of their internationalization process, because business environments in these countries are easier to understand. Although some authors (Claver et al., 2007; Graves \& Thomas, 2008) have investigated psychic distance in the internationalization process of FBs, these studies have covered the general patterns of internationalization. However, the impact of psychic distance on the FME of family SMEs remains a neglected research area, despite its importance to firms' FME indicated in several studies (Child, Ng \& Wong, 2002; Dow \& Karunaratna, 2006; Ellis, 2008).

The aim of this paper is to contribute to the understanding of the internationalization of family SMEs in the case where these firms enter a market that is geographically relatively close but psychically distant. Thus, four Finnish family-owned SMEs operating in the French market were selected as the target group. The French market can be conceptualized as being psychically distant from Finland due to cultural and linguistic differences (Irrmann, 2006; Trompenaars \& Hampden-Turner, 1997), but the European Union, on the contrary, eliminates all the formal restrictions for business. This research setting helps us to explore the internationalization pathways the family SMEs used prior to and during their FME into the French market and how psychic distance, in the form of distance-creating and distance-bridging factors, affected these processes. For the above discussed reasons, the following research questions are of particular interest for this study:

1) To what extent does psychic distance influence the overall internationalization process, and, more specifically, the FME and the entry mode choice of family SMEs when entering the French market? 
2) What kinds of distance-creating factors do family SMEs experience in the FME and their business operations in France?

3) How are family SMEs able to overcome these distance-creating factors?

\section{Literature review}

This section begins by reviewing the literature on internationalization process theory and by presenting how psychic distance is conceptualized. Thereafter, internationalization of SMEs is discussed in the context of psychic distance. Finally, literature related to the internationalization of family SMEs is presented.

\section{Internationalization and psychic distance}

Several traditional internationalization theories indicate that the internationalization of firms can be described as a step-wise process (Bilkey \& Tesar, 1977; Johanson \& Wiedersheim-Paul, 1975; Luostarinen, 1979) where firms internationalize their operations from nearby markets to more distant ones. According to the Uppsala-model, firms tend to favor nearby countries within a low psychical distance when they start their foreign operations and only thereafter expand their operations to psychically distant markets. This argument is related to the assumption that business environments in psychically nearby countries are easier to understand and make the business operations easier to implement. In their study, Johanson and Wiedersheim-Paul (1975, 308) define psychic distance as "...factors preventing or disturbing the flow of information between firm and market". These factors were mentioned to be related to differences in language, culture, political system, level of education and industrial development, etc. In addition to the actual internationalization process, the model describes the evolution of entry modes through four stages: 1. no regular export, 2. export through agents, 3 . founding an overseas sales subsidiary, and 4. own production.

Thus, the operations in a foreign country are supposed to start through indirect entry modes (stages 1-2), which do not require an own unit in the target country. Consequently, a firm's knowledge about the target country increases, with time, and the firm starts learn how to deal with the customers in that country. Once the country has become more familiar for the firm due to increased knowledge, direct operations (stages 3-4) can be established. However, the model does not include joint venture operations which are common in the foreign operations and require intermediate levels of knowledge and commitment.

Due to the fact that the Uppsala model conceptualizes psychic distance as a sum of factors inhibiting firms' internationalization, several scholars have solely investigated factors creating distances between countries (Brewer, 2007; Dow \& Karunaratna, 2006; Evans \& Mavondo, 2002). However, some scholars have indicated that psychic distance is not a stable phenomenon and it can be experienced in different ways (Child et al., 2002; Sousa \& Bradley, 2006). For instance, Sousa and Bradley $(2006,61)$ indicate that "psychic distance captures the manager's individual perception of the differences between the 
home and the host country and is a highly subjective interpretation of reality". Thus, some of the employees can be more conformable to differences between the home and the target country than others based on their earlier experiences. This distinguishes psychic distance from cultural distance, which has commonly been examined by measuring Hofstede's (2001) cultural values between countries. This means also that psychic distance can be overcome by actions made by a firm or an entrepreneur, also known as distance-bridging factors. For instance, the study of Child et al. (2002) reveals that actions taken by firms and managers' personal networks with trusted friends in foreign countries facilitate FME into a distant market. In addition, Nordström and Vahlne (1994) indicate that distance can be overcome by knowledge dissemination or trial and error processes.

\section{Internationalization of SMEs}

Internationalization of SMEs has emerged as an important research topic during the last decades, as earlier internationalization studies focused mainly on multinational corporations. Interest toward SMEs and their international activities has increased because these firms are very beneficial to local economies. SMEs create the majority of new jobs, open new market sectors, develop new products and services, and consequently generate potential multinational corporations (OECD, 2000; Ruzzier, Hisrich \& Antoncic, 2006). Internationalization of SMEs is commonly seen to be accelerated by the development of communication and transportation channels, homogenization of markets, and increasing international and cultural awareness (Autio 2005; Oviatt \& McDougall 2005). For these reasons, a number of researchers have concluded that the internationalization process of SMEs does not follow the traditional internationalization theories, such as the Uppsala model (Johanson \& Vahlne 1977; Johanson \& Wiedersheim-Paul 1975).

Empirical findings of studies investigating the internationalization of SMEs have been twofold. Some studies have found evidence that psychic distance has an impact on the market sequence of these firms, whereas others have not. In their study, Madsen and Servais (1997) indicate that the market selection of rapidly internationalizing SMEs is based on managers' past experiences and the existence of partners rather than on geographic or psychic distance between countries. The study by Crick and Jones (2000) also questioned the impact of psychic distance on the market selection of hightechnology SMEs. They argue that market selections are more related to growth opportunities of firms' niche products than psychic distance. On the other hand, some studies related to the internationalization of SMEs have found support for a sequent entry process, but authors have suggested alternative factors explaining internationalization as opposed to psychic distance between countries. In his study, Bell (1995) argues that customer followership, niche markets, and industry specific trends explained the internationalization of small software firms more clearly than psychic distance between countries. The study of Coviello and Martin (1999) also indicate that psychic distance has an impact on the internationalization of SMEs in consulting sectors. 
However, they argue that market entries were more related to entrepreneurs' formal in informal network relationships than impact of psychic distance.

In contrast, some studies related to the internationalization of SMEs have found support to step-wise internationalization process. In their study, Chetty and CampbellHunt (2004) argue that both traditional and rapidly internationalizing SMEs follow the logic of psychic distance by first entering psychically close countries and then subsequently psychically distant ones. Hashai and Almor (2004) investigated the internationalization process of rapidly internationalizing SMEs from Israel. Their findings reveal that these firms enter the psychically closest markets first in their internationalization process. However, the market entry process was reported as being faster than suggested in the Uppsala model. As most of the studies have investigated psychic distance in the general pattern of SME internationalization, studies by Ojala $(2008,2009)$ and Ojala and Tyrväinen (2009) investigated to the impact of psychic distance when SMEs are entering a certain target country. The findings in these studies indicate that although psychic distance created several challenges to Finnish software SMEs entering Japan, they were able to overcome these obstacles by utilizing different types of network relationships (Ojala, 2009) and by recruiting employees with relevant cultural and linguistic knowledge (Ojala, 2008; Ojala \& Tyrväinen, 2009). The importance of managers' foreign language skills in SMEs internationalization is also indicated in the study of Knowles, Mughan and Lloyd-Reason (2006). Thus, it seems that network relationships, cultural knowledge, and language skills are important distance-bridging factors for SMEs.

\section{Internationalization of family SMEs}

Internationalization of FBs has been studied since the beginning of 1990s, but only recently, the theme has attracted more attention. Nevertheless, the studies about FB internationalization generally focus on FBs of all sizes. Hence, the research papers dealing with family SMEs are not numerous. In this section we will discuss FB internationalization in general before moving on to the internationalization of family SMEs.

According to current studies, FBs are less likely to internationalize than their nonFBs counterparts (Fernández \& Nieto, 2005; Graves \& Thomas, 2006). This might be due to limited growth aspirations (Donckels \& Fröhlich, 1991) and restricted financial capital (Gallo \& Pont, 1996) of family firms. Limiting factors in FB internationalization are considered to be mainly organizational, such as not recruiting outside expertise for the process, internationalization with small management teams, and the difficulty with hiring new managers with international responsibility (Gallo \& Sveen, 1991; Graves \& Thomas, 2006). On the contrary, Crick. Bradshaw and Chaudry (2006) in their investigation into successful family SMEs found that family SMEs hired outside 
expertise in the context of internationalization because of their strong commitment to the business and family.

All in all, family involvement in management has been indicated to cause cautiousness in internationalization process of FBs (Claver, Rienda \& Quer, 2008). Thus, it is more likely that FBs take a traditional pathway to internationalization (Claver et al., 2007) and proceed sequentially (Graves \& Thomas, 2008). Harris et al. (1994) and Claver et al. (2007) found that FBs tend to choose psychically close countries when expanding globally. As to operation modes, Pinho (2007) found that FBs did not prefer indirect entry modes to direct entry modes and, hence, did not differ from non-FBs. In the foreign direct investment process, FBs have been suggested to have a less formal and structured way of collecting information and conducting analysis than non-FBs (Tsang, 2002). Fernandez and Nieto (2006) suggest that, all in all, it might be harder for FBs to build a portfolio of strategic resources than for firms with corporate governance, causing difficulties in the success of international business.

Although, as indicated in the previous paragraph most family SMEs take a traditional pathway to internationalization, indicating a sequential process (Graves \& Thomas, 2008); some family SMEs were seen to take born-again global pathways, in other words, a rapid internationalization strategy that could take place in the context of succession of the firm to the next generation (Graves \& Thomas, 2008). A central determinant in the internationalization pathways of family SMEs was the ability to develop the firm's international network of relationships and, especially, their production, managerial, and marketing capabilities: the firm needed to change from a production mindset to a more customer oriented mindset (Graves \& Thomas, 2008).

The decision-making process of family SMEs in the context of internationalization is regarded as being informal, unstructured and founder-centered (Tsang, 2001). Decision-making is based on the intuition of the founder, and other managers, especially non-family members, learned very little from the process (Tsang, 2001). Family SME owners did not borrow from external sources to facilitate their outside expansion, and the decision to internationalize was found to be related to longer term strategic reasons (Thomas \& Graves, 2005). Nonetheless, unless family SME managers had the freedom to act autonomously, the ability to benefit internationally from such an innovation capability might be limited (Thomas \& Graves, 2005). Tsang (2001) also found that a long time was required to build trust in a non-family member involved in business operations. Interestingly, the enterprise culture, architecture, decorations etc. of the headquarters were duplicated in the target country (Tsang 2001, 2002). Concerning networking, family SMEs were considered less likely to engage in networking with other businesses than did non-family SMEs (Thomas \& Graves, 2005).

\section{Summary of the literature review}

Empirical findings related to internationalization of FBs have found evidence that FBs internationalize their operations gradually because of the specific nature of their business. This equates to the internationalization process of firms described in the 
Uppsala model. However, the impact of psychic distance on FME of family SMEs remains unresolved as earlier studies have focused solely on the general pattern of internationalization where a firm internationalizes its operations from home country to several foreign markets. In addition, there is no evidence of the specific factors creating distances in FME and how the firms are able to overcome these distance-creating factors. By focusing on these issues, the present paper contributes to the understanding of the internationalization process, FME and entry mode choice of family SMEs.

\section{Methodology}

Multiple case-study method was selected for this study due to the explanatory nature of the research questions. It enables in-depth investigation and explanation of cause-andeffect relationships (Yin, 1994). As advised in the study of Eisenhardt (1989), the case firms were selected for theoretical reasons instead of random sampling. The selected case firms were family owned small or medium-sized Finnish enterprises having operations in the French market. All the case firms were from manufacturing sector and had a maximum of 250 employees. Thus, they fulfilled the Finnish government's and EU's criteria for SMEs having 250 or less employees (OECD, 2003). Consistent with the earlier literature, for instance Graves and Thomas (2008), this study defines a family firm as one that is majority family owned and has at least one family member in the management team.

Finland was chosen as the country of origin due to its small and open economy and limited domestic market where internationalization is a common growth strategy. The main reason for choosing France as a target country of this study was the interest in the possible impact of psychic distance on the market entry. Despite its geographical closeness to Finland, France is culturally different. In Trompenaars' and HampdenTurner's (1997) seven-scope cultural model Finland and France belong to different ends in several cultural classifications. Irrman (2006) also stated in his study concerning communication in Finnish-French mergers and acquisitions that Finnish and French had many conflicts due to their cultural differences, especially differing ways of communication. Thus, as both countries belong to the European Union that eliminates all formal entry barriers, the difficulties in business might be more related to perceived differences by entrepreneurs.

Altogether six semi-structured open-ended interviews were conducted with managers in each firm. In the first round, realized in 2004, all the case firms were studied by conducting face-to-face interviews with one informant per firm. Within the second round, executed in 2008, two new informants from the medium-sized firms A and $\mathrm{C}$ were interviewed by using a telephone and a face-to-face interview. In addition, many types of secondary information (websites and annual reports, etc.) were collected and analyzed. All the interviews lasted from 60 to 90 minutes. The respondents were people that were actively involved in the internationalization process, except in Firm B where the informant was the current international business manager. However, Firm B had a good documentation about its whole history, including internationalization to 
France. Table 1 summarizes the key information on the case firms. Firms were established between 1876 and 1967. The number of personnel varies from 18 to 249 employees, the average being 122 employees.

Table 1. Key information on the case firms

\begin{tabular}{|l|c|c|c|c|}
\hline & $\begin{array}{c}\text { Number of } \\
\text { employees }\end{array}$ & $\begin{array}{c}\text { Year of } \\
\text { establishment }\end{array}$ & $\begin{array}{c}\text { Beginning of } \\
\text { internationalization }\end{array}$ & $\begin{array}{c}\text { Entry to } \\
\text { France }\end{array}$ \\
\hline Firm A & 249 & 1876 & 1970 s & 1982 \\
\hline Firm B & 18 & 1923 & 1929 & 1968 \\
\hline Firm C & 200 & 1967 & 1980 s & 1997 \\
\hline Firm D & 20 & 1973 & 1990 s & 1998 \\
\hline
\end{tabular}

All the interviews were digitally recorded, carefully listened to and transcribed verbatim with the help of a word processor. During the second listening, the correspondence between recorded and transcribed data was accurate. Complete case reports were sent back to interviewees, and all the inaccuracies they noticed were corrected based on their comments. In addition, email communication was used to collect further information from the interviewees if needed. In the analysis phase, all four individual cases were written up as stand-alone case histories. Secondly, the unique patterns of each case were identified and similar patterns were categorized under themes based on the three research questions in this study. Also checklists and event listings were used to identify critical entry events related to internationalization process, FME, and entry mode choice of each firm.

\section{Findings}

\section{Entry into the French market}

As illustrated in Figure 1, all the case firms started to operate internationally between six and ninety-four years after the date of establishment. Firm B started to internationalize in 1929, Firm A in 1970, and Firms C and D in the beginning of 1990s. Firms A, B and C exported first to Sweden and Firm D to Germany. Countries typically following Sweden and Germany were other Nordic countries and England. Firms B and D exported as far as to Japan, Argentina and the USA before entering France. France was between the third and the eighth country to enter for the case FBs. 


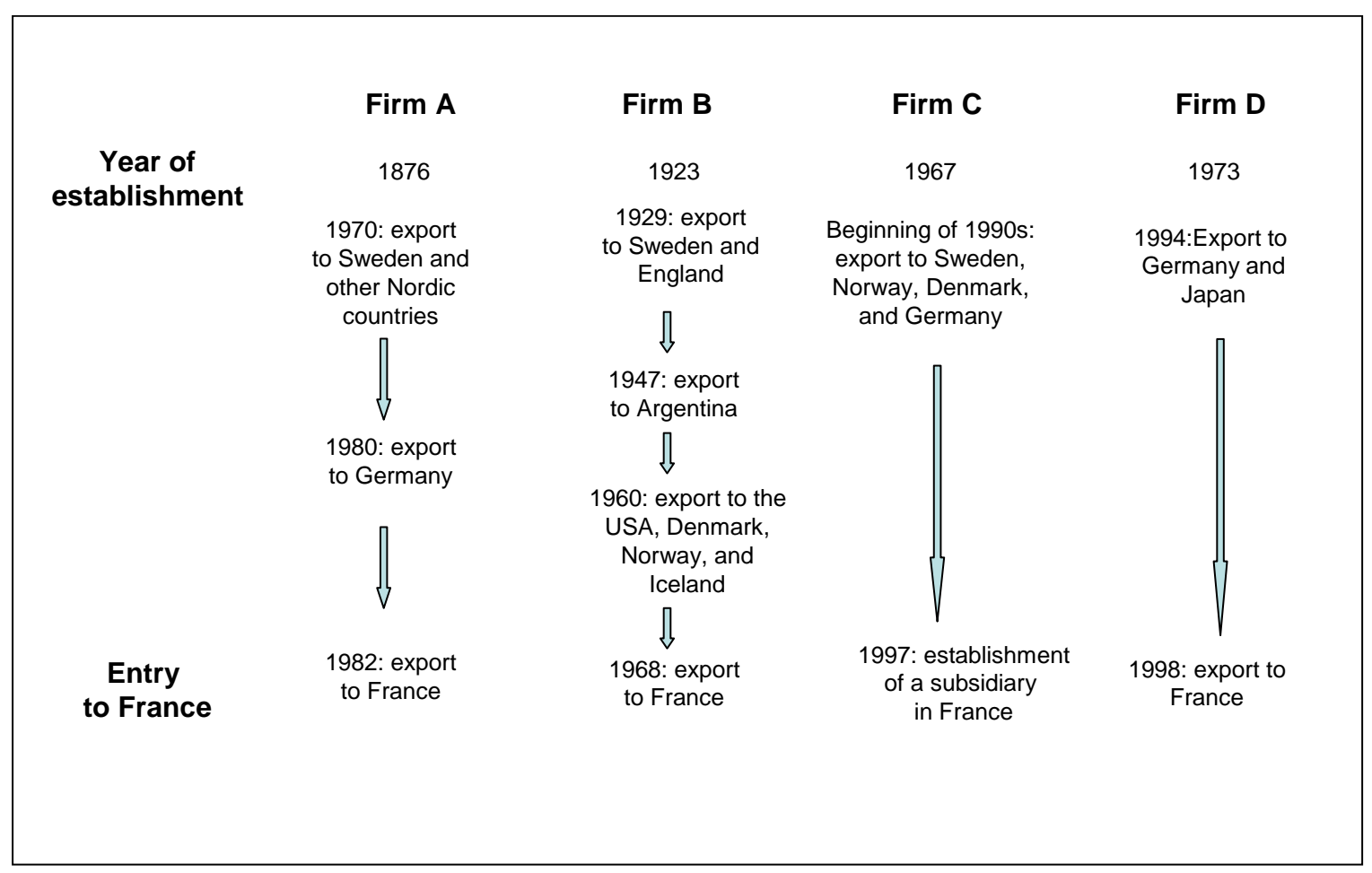

Figure 1. Internationalization pathways before the entry to France.

Firm A entered the French market in 1982, having found an agent who was interested in selling their product in France. This was preceded by market research and participation of Firm A in an trade exhibition. The product suited and completed the product range of the agency. Advantageously, the distribution channel and customer contacts were already in place. The first products were sold in 1983, as soon as the agent started marketing the product of Firm A. After two years of direct export, in 1985, Firm A set up a subsidiary in France by buying the agency. Firm B has a long history of trading internationally. The firm has been selling to France since 1968, and they have used the same agent for forty years. Their product is designed and produced in Finland and sold around the world by using direct exporting.

For Firm C, the first entry mode into the French market was the establishment of a subsidiary. As the product of Firm $C$ was large-sized and expensive, its usefulness could only be proved by showing how the machine works in practice, and Firm $\mathrm{C}$ saw no other strategy to accomplish it. With their second, smaller product, Firm $C$ entered France by using direct exporting, and it is also the present mode of operation. Also Firm D entered France in 1998 by using direct exporting. For the four first years, it tried to search for local agents, but, finally, due to the lack of suitable work force, they ended up selling the product themselves and established a representative office in France in 2002. An element of cautiousness was a feature of all the entry processes, most probably stemming from family presence. One of the informants in Firm A put it this way:

The presence of family [in the business] is perceivable in the form of cautiousness about everything. All the decisions are made with a lot of consideration. There were no big investments because of the cautiousness [during the entry process]. 
Thus, all the case firms have operated in France with indirect entry modes, and Firms B and C have only indirect entry modes at present, as Firm C sold out its subsidiary in 2007 with management-buy-out because of rationalization. Firm B, on the contrary, has never proceeded from the phase of indirect modes to direct operations. Firms A and D operate in France with direct entry modes: Firm A has a subsidiary and Firm $\mathrm{D}$ a representative office. Figure 2 illustrates the operations taken by the case firms in France dividing the entry modes into direct and indirect modes according to stages 12 and 3-4 in the Uppsala model (Johanson \& Wiedersheim-Paul, 1975).

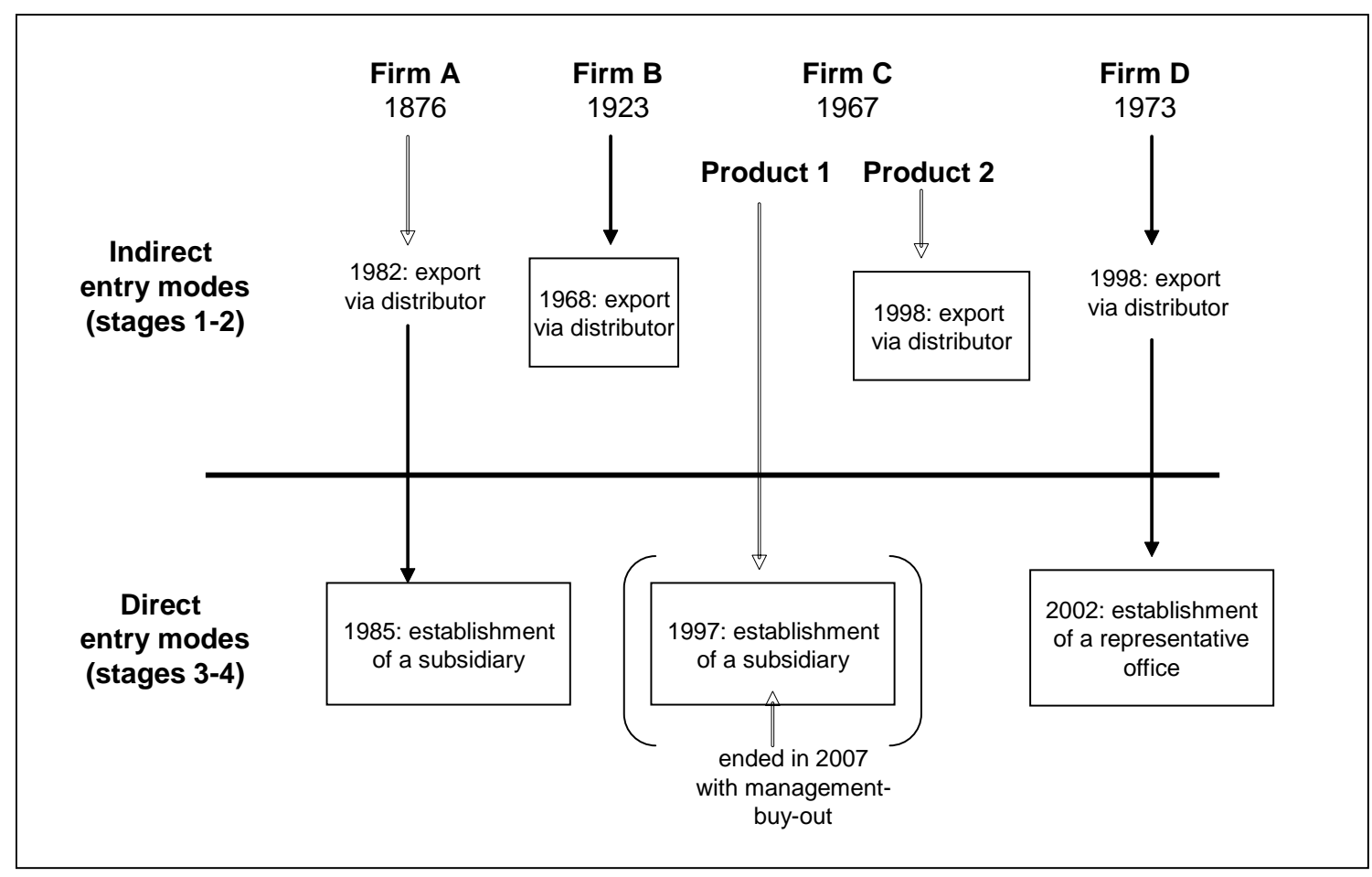

Figure 2. The operations of the case firms in the French market. 


\section{Distance-creating factors in the entry to France}

France was experienced as a difficult country to enter by all the case firms. The main distance-creating factors encountered during the process of internationalization to France were related to differences in language and business culture. Language was regarded as a distance-creating factor in entering the French market by all four cases. The high level of English proficiency of the staff in case firms was irrelevant, due to the low English proficiency level as well as the negative attitudes of French customers and partners towards the use of English. French language skills were regarded to be a prerequisite with French customers as well as an obvious advantage with French partners.

The distance-creating factors related to business culture elicited in the research included the relationship orientation of the French, the difficulty of building trusting relationships, their disinterest in rules, orders and schedules, hierarchical management, and their different temperament. The relationship orientation of the French customers and partners was emphasized by all the informants: they recognized that one should always have time to socialize with the French, because they preferred processing facts orally as opposed to communicating for instance via email. Working in the Finnish way (efficiently for the whole day with small pauses) was not compatible with French business life. In the Firms A, C and D it was experienced that socializing and breaks, as well as long dinners, were the core of French business life.

It was pointed out that also for French clients, the seller of the product was usually not only a salesman of a firm, but also a friend that one respected and socialized with. Controversially, the building of trustful relationships was stated to be difficult by all the case firms. French people wanted to know the person thoroughly before they were ready to talk about business, and gaining their trust demanded even more time. In addition to the time needed to build trustful relationships, Firms A, C and D had to meet some kind of immoral behavior by the French partners and customers before establishing good relations with them. In Firm C, gaining the trust of the French was expressed accordingly:

It really takes time to have the trust of the French, and there can be many kinds of problems and misbehavior in the meanwhile.[...] But once they trust you, they are extremely friendly and they become family friends that you meet also in your free time.

The disinterest of the French in schedules, rules, and orders was regarded as a distance-creating factor in all the firms. Regarding the FME, the agents of Firm D gave incorrect information about the company, the product and its use. As to business operations, there were delays in reporting on the part of partners and/or payments in the part of customers and partners in all the case firms. In addition, the French partners of Firms A and D often did not take the rules and orders set by the headquarters into consideration, although the need to obey them was discussed constantly. In Firms $\mathrm{C}$ and $\mathrm{D}$, also the French customers were perceived to have a nonchalant behavior: they did 
not take care of the products as recommended, and it caused problems with the success of the product.

The hierarchical management style was experienced to be a distance-creating factor, as well. It affected significantly the behavior of the partners and customers who needed to be very formal and respect their manager in all possible circumstances. For instance, in Firm A they did not tell the headquarters if they had problems with their subsidiary manager. Also the French temperament, the tendency to express their views strongly, was experienced equivocal in all the case firms.

Ways of overcoming psychic distance

Although France was experienced as a psychically distant country to Finland, the case firms learned to cope with the psychic distance. Actions that helped with overcoming the psychic distance included the recruitment of capable employees, the building of networks, learning the French language and familiarizing with French culture, choice of proper entry mode, earlier experiences, honest, trustworthy and friendly attitude, and familiarizing the French with the Finnish culture.

The recruitment of capable employees, with both cultural, language and business/industry knowledge helped the case firms with overcoming psychic distance. Firms $\mathrm{A}$ and $\mathrm{C}$ proceeded at a more rapid pace in the French market as their employees possessed French language skills, were familiar with aspects of French culture, in particular French business culture and possessed deep industry knowledge. In Firm C, the Finnish subsidiary manager with 20 years of experience of doing business in France was an excellent facilitator in overcoming psychic distance: she operated as an absorptive person between the two different cultures, transforming the messages of the French customers in the form understandable for Finns and vice versa. Also Firm B found a good agent, which resulted in gradual increases in sales. Firm D, on the contrary, the French-speaking person of which had only language and cultural skills but no technological know-how in the beginning the process had difficulties in France in the beginning. One informant in Firm A illustrates the need for local staff this way:

If we had sent there Finnish personnel that does not even know their language, we could have forgotten about this all [the French entry]. In France there definitely has to be a local personnel. [...] And for us it was a big advantage that our manager of that time had fluent French skills and a good cultural knowledge when we started our entry process. He had spent several years in France and knew what it all was about.

Networks proved to be extremely important in entry to France in all the case firms. The most important networks were the French agents/entrepreneurs with whom the firms started business in France, and who already had a customer base and other important networks necessary to operate in France. In addition, networking and cooperation with organizations, such as the French-Finnish Chamber of Commerce in Paris and Finpro (Finnish export promotion organization) were good facilitators in 
overcoming psychic distance. Firm $\mathrm{C}$ also used the French-Finnish Chamber of Commerce to find a suitable entrepreneur in France before its entry to France. Firms A, $\mathrm{B}$ and $\mathrm{D}$ did not use such organizations in their entry phase, but all of them cooperated with Finpro in the beginning of the $21^{\text {st }}$ century to enhance their networks in France.

The choice of proper entry mode also helped with decreasing psychic distance. Firm C knew that selling forest machines required presence in France, and, establishing a subsidiary was the right way to operate. Also Firm A had already originally the aim of establishing a subsidiary in France to guarantee local services. For Firm B, export is the only mode of operation globally, and France is no exception. Exporting is a strategic decision suitable for their niche, long-lasting product. Also Firm D has proceeded from export to representative office, to serve the customers better and to get better knowledge about the market.

Learning to know the French language and culture proved to be an excellent way of overcoming psychic distance. All the informants learned about French language and culture aside doing business in the French market. They stated that when one spoke fluent French and knew the history of the country, doing business in France was much easier. In addition, there was a general conception in all the case firms that both the French and the Finnish cooperators came closer to each other's cultures during the internationalization process, trying to understand each other better.

Earlier experiences from abroad were also helpful for overcoming psychic distance. As stated above, all the case firms had experience from other countries before entering France, and it had given them the opportunity to acquire some general knowledge about operating abroad. For instance Firm A established subsidiaries in Sweden and in Germany before setting up one in France: as its Swedish subsidiary established by their Finnish employee proved to be an unsuccessful strategy, although Sweden might be a culturally close country to Finland, their view of having a local entrepreneur in the French market strengthened.

Due to the length of time required to build trusting relationships, there was an agreement in the case firms that one's honest, friendly, and trustworthy behavior decreased psychic distance with time. The informant in the subsidiary of Firm C saw that the sometimes immoral behavior and sentimentalism of the French just needed to be accepted. Two informants (in Firms B and C) experienced that familiarizing the French with the Finnish culture, especially its composers, singers, and conductors, in a modest way, helped with the development of business relationships.

\section{Discussion}

As the case findings revealed, all the firms operated first in the domestic market for a period between six and 94 years, and only thereafter started their international operations. Firms A, B, and C entered first Nordic countries, whereas Firm D made an exception entering directly Germany and Japan. Thus, France was seen as a target country in a rather late phase of the internationalization process. This supports Claver et al. (2007) and Harris et al. (1994) who concluded that FBs are more likely to choose 
psychically close countries when expanding globally. This also endorses the findings of Graves and Thomas (2008), who indicated that family SMEs follow a sequential internationalization process. However, findings are, as it might be assumed, inconsistent with the literature investigating the internationalization process of rapidly internationalizing SMEs (Crick \& Jones, 2000; Madsen \& Servais, 1997). In their entry mode choices, Firms A, B and D entered France by using indirect entry modes first. Firm C entered France by exporting via independent representatives with its second product, but their first entry was direct as they established a subsidiary in France. This is in contrast to Pinho (2007) who claimed that FBs do not prefer indirect entry modes to direct entry modes. Altogether, findings related to the internationalization process before entering France and entry mode choices in France are in line with the Uppsala model (Johanson \& Vahlne, 1977). This might be due to the tendency of FBs to secure the long-term growth by avoiding gambling family money and proceeding slowly by making only minor investments (Donckels \& Fröhlich, 1991).

There were several indicators proving that France was experienced as a psychically distant country and the case firms encountered several distance-creating factors. Although English is a commonly spoken language in international business, the French partners preferred speaking in French. This represents a challenge for family SMEs who do not tend to have versatile language skills. This is also inline with earlier studies indicating the importance of foreign language skills in the internationalization process (Knowles et al., 2006) and in the entry to a psychically distant country (Ojala, 2008; Ojala \& Tyrväinen, 2009). Secondly, in France, a long time was needed to find partners and building trustful relationships. This is in line with Tsang (2001) suggesting that in family SMEs, a long time was required to trust a non-family member involved in business operations. In the case firms, this was, nevertheless, seen as a quality of their partners not being able to trust them quickly. For family SMEs, in which the inner trust is generally of high level (Sundaramurthy, 2008), all the actions are controlled, and relationships are very close, understanding and accepting the lack of trust is especially difficult. All in all, it seems that the establishment of network relationships with foreign partners is more challenging for family SMEs than other types of SMEs (c.f., Coviello \& Martin, 1999). This supports Graves and Thomas' findings (2008) suggesting that an essential determinant in the internationalization of family SMEs is the ability to develop a network of relationships. These case firms succeeded in developing such a network, although it proved challenging.

Thirdly, the hierarchical management style made the French employees very formal and respective towards their French managers. However, the French managers did not feel that kind of respect for the managers in the Finnish headquarters and they made decisions themselves, in contrast to orders. This may prove to be especially demanding for family SMEs in which the decision-making process is often based on the intuition of the owner (Tsang, 2001). Thus, the strong management style that is typical for FBs (Gallo \& Pont, 1996) did not seem to suit the French partners who liked to make decisions themselves. This also supports Thomas and Graves (2005) who suggest that the ability of family SMEs to act autonomously and innovatively might be limited in the 
international context. Spreading decision-making power might, nontheless, be especially demanding for family SMEs that are used to centralized decision-making and have a strong, inner enterprise culture (Gallo \& Sveen, 1991). Fourthly, other distance-creating factors encountered were different work styles, hours of working, the French relationship orientation and temperament. These issues were demanding for Finnish family SMEs that are used to a different style of working. It might be especially demanding for family SMEs who are accustomed to duplicating their domestic enterprise culture in the target market (Tsang 2001, 2002). Altogether, the psychic distance view (Child et al., 2002; Ojala \& Tyrväinen, 2009; Sousa \& Bradley, 2006) related to managers perceptions of psychic distance seemed to describe well the different aspects in the FME and operations of the case firms.

Although the family SMEs met many distance-creating factors, they were able to operate in France as they found ways, so called distance-bridging factors, to overcome them. The family SMEs were able facilitate and accelerate their entry into the French market by recruiting local knowledgeable employees, by simultaneously learning the language and the culture themselves. This corresponds to the findings by Coviello and Martin (1999) and Ojala (2008). However, FBs seem to be more motivated to increase their own knowledge about foreign languages and cultures than reported in the earlier studies (Coviello \& Martin, 1999; Ojala, 2008) which focused on SMEs on service and knowledge-intensive sectors that acquire knowledge mainly through recruiting. This might be connected to the founder-centeredness of running a family SME (Tsang, 2001) and the will to control everything (Gallo \& Sveen, 1991). Secondly, network relationships played a remarkable role in overcoming distance-creating factors. With the help of network relationships, the case firms were able to start the entry process and solve market-specific problems. This is in line with other studies indicating the important role of network relationships in overcoming psychic distance (Child et al., 2002; Coviello \& Martin, 1999). This also gives support to Graves and Thomas (2008) suggesting that the ability to develop a firm's international network relationships, is a central determinant in the success of the internationalization pathways of family SMEs. In addition to personal and business networks, relationships with organizations, such as Finpro, were regarded as a good way of decreasing psychic distance. The importance of network relationships with non-profit organizations is also indicated in the study of Ojala (2009). Thirdly, the selection of proper entry mode suitable for the product also seemed to decrease perceived psychic distance. The firms first favored indirect entry modes (except Firm C) which enabled them to enter the market with lower risks and the acquisition of market knowledge from France before direct entry modes. Fourthly, earlier experiences from other markets helped the case firms, e.g., assessing suitable strategies for the country with a different culture. Finally, the case firms continuously operated in France in an honest, friendly, and trustworthy manner as well as familiarizing the French with the Finnish culture. These actions seemed to decrease psychic distance with time. 


\section{Summary and Conclusions}

This paper contributes to research in the area of the internationalization of family SMEs in a number of ways. Firstly, it validates and extends earlier findings concerning the internationalization pathways taken by family SMEs. In line with these studies (Claver et al., 2007; Graves \& Thomas, 2008), FBs are more likely to choose psychically close countries and proceed step-wise favoring first indirect entry modes. Secondly, this study investigated psychic distance in the context of FME and operations into a certain market, and as distinct from other studies concerning family SMEs (e.g. Graves \& Thomas, 2006, 2008), not the general pattern of internationalization. It revealed what kinds of distance-creating factors family SMEs encountered in their FME and operations in France. In spite of geographical closeness and the free trade area offered by the European Union, France was considered a distant country by all the case firms, mainly for linguistic and cultural reasons. However, it seems that the experienced psychic distance made the firms perform well in France: they needed to think carefully how to succeed there, because the French did not accept the Finnish way of doing things. Thirdly, this paper analyzed how the case firms were able to overcome psychic distance between Finland and France. They used so called distance-bridging factors, such as recruited local, skilled employees, while learning to know the language and the culture themselves. It appears that family SMEs are more motivated to learn foreign languages and cultures themselves than other types of SMEs (Coviello \& Martin, 1999; Ojala, 2008). This might be due to their limited financial resources (Smyrnios \& Walker, 2003), but also their unwillingness to hire employees from outside the firm (Graves \& Thomas, 2006). However, hiring managers from outside the own firm might increase the level of success of the internationalization in the family SMEs (Crick et al., 2006).

Altogether, this paper highlights the important role of psychic distance in the internationalization process and the FME of family SMEs. Although the importance of psychic distance to the internationalization process has been indicated in several studies (Child et al., 2002; Dow \& Karunaratna, 2006; Ellis, 2008), its detailed impact on the internationalization process of FBs, especially in their FME and entry mode choice, has been an uncovered topic. It can be argued that psychic distance has a stronger role in the internationalization process of family SMEs than, for instance, in that of rapidly internationalizing SMEs, operating mostly in knowledge-intensive industries (Crick \& Jones, 2000; Madsen \& Servais, 1997). Reasons for this might be that FBs generally have an emotional attitude to running the business. Current and future generations are dependent on their business and how the firm proceeds in new markets. In contrast, knowledge-intensive SMEs are, in many cases, forced to enter the leading markets to acquire sufficient market share for their niche products (Ojala, 2008). Although FBs are slow and cautious when they decide to operate abroad (Donckels \& Fröhlich, 1991), by proceeding step-wise, they avoid big risks that might harm the whole family. 


\section{Managerial implications}

From a managerial perspective, when entering psychically distant markets, managers of FBs should be provided with the capacity to overcome all the distance-creating factors that they might encounter. They should be prepared to use several facilitators in overcoming psychic distance, for instance recruiting local skilled employees with cultural, language, business and industry-specific knowledge, building good networks, selecting a proper entry mode etc. However, as a specific challenge for FBs, the entry mode should also suit the objectives of the family. Managers of FBs themselves should also be prepared to operate in the target market according to its norms, values and habits. Thus, they should be ready to acquire knowledge about the language and the culture in the target country by learning themselves or through recruiting. For instance, in France, there should be time reserved for socializing, because the French generally prefer processing things orally and they want to know the person properly before talking about business. For the generally open-minded FBs, the knowledge of the target culture and their human attitude to business can be a crucial competitive advantage. Managers of FBs should understand that the decision to internationalize is a strategic decision that will most probably change the historical harmony of the firm.

\section{Limitations and further research}

When evaluating the results of this study, some limitations have to be considered. This research applies the case study method. As it is commonly known, generalization of case results is low. On the other hand, analytical generalizations proposed by Yin (1994) are possible in case studies. Nevertheless, the case study method made it possible to acquire detailed knowledge about the firms' entry process, distance-creating factors, and ways to overcome psychic distance, also called distance-bridging factors, in the entry to the French market. Thus, we were able to get a more holistic understanding of the theme. Secondly, this study used case firms from one home country, and analyzed entries to a certain host country. Despite these limitations, we hope that these findings could be a starting point to better understanding of internationalization pathways and the FME of family SMEs, the psychic distance encountered and ways to overcome it. In the future, it would be useful to tackle the present research from the point of views of cross-cultural competence and cultural sensitivity. In addition, networks relationships that family SMEs use in their market entry seem to have an important role in overcoming psychic distance. Thus, a further study concerning the impact of network relationships on the internationalization and FME of family SMEs could offer new insights. 


\section{References}

Autio, E. (2005), “Creative tension: the significance of Ben Oviatt's and Patricia McDougall's article 'toward a theory of international new ventures'," Journal of International Business Studies, Vol. 36 No. 1, pp. 9-19.

Bell, J. (1995), "The Internationalization of Small Computer Software Firms: A Further Challenge to "Stage" Theories," European Journal of Marketing, Vol. 29 No. 8, pp. 6075.

Bilkey, W. and Tesar G. (1977), "The export behaviour of smaller-sized Wisconcin manufacturing firms," Journal of International Business Studies, Vol. 8 No. 1, pp. 93-98.

Brewer, P.A. (2007), "Operationalizing psychic distance: A revised approach," Journal of International Marketing, Vol. 15 No. 1, pp. 44-66.

Chetty, S.K. and Campbell-Hunt C. (2004), "A Strategic Approach to Internationalization: A Traditional Versus a "Born-Global" Approach," Journal of International Marketing, Vol. 12 No. 1, pp. 57-81.

Child, J., Ng, S.H. and Wong, C. (2002), "Psychic distance and internationalization: Evidence from Hong Kong firms," International Studies of Management $\mathcal{E}$ Organization, Vol. 32 No. 1, pp. 36-56.

Claver, E., Rienda, L. and Quer, D. (2008), "Family firms' risk perception: Empirical evidence on the internationalization process," Journal of Small Business and Enterprise Development, Vol. 15 No. 3, pp. 457-471.

Claver, E., Rienda, L. and Quer, D. (2007), “The internationalization process in family firms: Choice of market entry strategies," Journal of General Management, Vol. 33 No. 1, pp. 1-14.

Coviello, N.E. and Martin, K.A.-M. (1999), "Internationalization of service SMEs: An integrated perspective from the engineering consulting sector," Journal of International Marketing, Vol. 7 No. 4, pp. 42-66.

Crick, D., Bradshaw, R. and Chaudhry, S. (2006), "'Successful' internationalizing UK family and non-family-owned firms: a comparative study," Journal of Small Business and Enterprise Development, Vol. 13 No. 4, pp. 498-512.

Crick, D. and Jones M.V. (2000), “Small High-Technology Firms and International HighTechnology Markets," Journal of International Marketing, Vol. 8 No. 2, pp. 63-85.

Donckels, R. and Fröhlich, E. (1991), "Are family businesses really different? European experiences from STRATOS," Family Business Review, Vol. 4 No. 2, pp. 149-160.

Dow, D. and Karunaratna, A. (2006), "Developing a multidimensional instrument to measure psychic distance stimuli," Journal of International Business Studies, Vol. 37 No. 5, pp. 578-602.

Eisenhardt, K.M. (1989), "Building theories from case study research," Academy of Management Review, Vol. 14 No 4, pp. 532-550.

Ellis, P.D. (2008), "Does psychic distance moderate the market size-entry sequence relationship?" Journal of International Business Studies, Vol. 39 No. 3, pp. 351-369. 
Evans, J. and Mavondo, F.T. (2002), "Psychic distance and organizational performance: An empirical examination of international retailing operations," Journal of International Business Studies, Vol. 33 No. 3, pp. 515-532.

Fernandez, Z. and Nieto, M.J. (2006), "Impact of ownership on the international involvement of SMEs," Journal of International Business Studies, Vol. 37 No. 3, pp. 340351.

Fernandez, Z. and Nieto, M.J. (2005), "Internationalization strategy of small and medium-sized family businesses: Some influential factors," Family Business Review, Vol. 18 No. 1, pp. 77-89.

Gallo, M.A., and Pont, C.G. (1996), "Important factors in family business internationalization," Family Business Review, Vol. 9 No. 1, pp. 45-59.

Gallo, M.A., and Sveen, J. (1991), "Internationalizing the family business: Facilitating and restraining factors," Family Business Review, Vol. 4 No. 2, pp. 181-190.

Graves, C. and Thomas, J. (2006), "Internationalization of Australian family businesses: A managerial capabilities perspective," Family Business Review, Vol. 19 No. 3, pp. 207-224.

Graves, C. and Thomas, J. (2008), "Determinants of the internationalization pathways of family firms: An examination of family influence," Family Business Review, Vol. 21 No. 2, pp. 151-167.

Harris, D., Martinez, J.I. and Ward, J.L. (1994), "Is strategy different for the familyowned business?" Family Business Review, Vol. 7 No. 2, pp. 159-174.

Hashai, N. and Almor, T. (2004), "Gradually internationalizing 'born global' firms: an oxymoron?," International Business Review, Vol. 13 No. 4, pp. 465-483.

Hofstede, G. (2001), "Culture's consequences", (2nd ed.). Thousand Oaks (Calif.): Sage.

Irrmann, O. (2006), "Intercultural communication and the integration of cross-border acquisitions," Doctoral dissertation. Helsinki School of Economics, Helsinki.

Johanson, J. and Vahlne, J.-E. (1977), "The internationalization process of the firm: A model of knowledge development and increasing foreign market commitments," Journal of International Business Studies, Vol. 8 No. 1, pp. 23-32.

Johanson, J. and Wiedersheim-Paul, F. (1975), "The internationalization of the firm: Four Swedish cases," Journal of Management Studies, Vol. 12 No. 3, pp. 305-322.

Knowles, D., Mughan, T. and Lloyd-Reason, L. (2006), "Foreign language use among decision-makers of successfully internationalized SMEs: Questioning the languagetraining paradigm," Journal of Small Business and Enterprise Development, Vol. 13 No. 4, pp. 620-641.

Luostarinen, R. (1979), “Internationalization of the firm," Doctoral dissertation, Helsinki School of Economics, Helsinki.

Madsen, T.K. and Servais, P. (1997), "The Internationalization of Born Globals: an Evolutionary Process?," International Business Review, Vol. 6 No. 6, pp. 561-583.

Miller, D. and Breton-Miller, I.L. (2006), "Family governance and firm performance: Agency, stewardship, and capabilities," Family Business Review, Vol. 19 No. 1, pp. 7387. 
Nordström, K.A. and Vahlne, J.-E. (1994), "Is the Globe Shrinking? Psychic Distance and the Establishment of Swedish Sales Subsidiaries during the Last 100 Years," in International Trade: Regional and Global Issues, Michael Landeck, (Ed.), New York: St. Martin's Press, pp. 41-56.

OECD (2000), "Small and Medium-sized Enterprises: Local Strength, Global Reach," Organisation for Economic Co-operation and Development. OECD Observer, June.

OECD (2003), "Officially-supported export credits and small exporters," France: Organization for Economic Co-operation and Development.

Ojala, A. (2009), "Internationalization of knowledge-intensive SMEs: The role of network relationships in the entry to a psychically distant market," International Business Review, Vol. 18 No. 1, pp. 50-59.

Ojala, A. (2008), "Entry in a psychically distant market: Finnish small and medium-sized software firms in Japan," European Management Journal, Vol. 26 No. 2, pp. 135-144.

Ojala, A. and Tyrväinen, P. (2009), "Impact of psychic distance to the internationalization behavior of knowledge-intensive SMEs," European Business Review, Vol. 21 No. 3, 263-277.

Oviatt, B.M. and McDougall P.P. (2005), "Defining international entrepreneurship and modeling the speed of internationalization," Entrepreneurship Theory and Practice, Vol. 29 No. 5, pp. 537-553.

Pinho, J.-C. (2007), "The impact of ownership: Location-specific advantages and managerial characteristics on SME foreign entry mode choices," International Marketing Review, Vol. 24 No. 6, 715-734.

Ruzzier, M., Hisrich, R.D. and Antoncic, B. (2006), "SME internationalization research: past, present, and future," Journal of Small Business and Enterprise Development, Vol. 13 No. 4, pp. 476-497.

Smyrnios, K.X., Walker, R.H. (2003). "Australian family and private business survey". Melbourne, Australia: RMIT University.

Sousa, C.M.P. and Bradley, F. (2006), “Cultural distance and psychic distance: Two peas in a pod?" Journal of International Marketing, Vol. 14 No. 1, pp. 49-70.

Sundaramurthy, C. (2008), "Sustaining trust within family businesses," Family Business Review, Vol. 21 No. 1, pp. 89-102.

Thomas, J. \& Graves, C. (2005), "Internationalising the family firm as a demonstration of an entrepreneurial culture," Journal of Business and Entrepreneurship, Vol. 17 No. 2, 91-113.

Trompenaars, F. and Hampden-Turner, C. (1997), "Riding the waves of culture: Understanding cultural diversity in business," (2nd ed.) Nicholas Brealey, London.

Tsang, E. W. K. (2001), "Internationalizing the family firm: A case study of a Chinese family business," Journal of Small Business Management, Vol. 39 No. 1, 88-94.

Tsang, E.W.K. (2002), "Learning from overseas venturing experience the case of Chinese family businesses," Journal of Business Venturing, Vol. 17 No. 1, pp. 21-40.

Yin, R.K. (1994), "Case study research: Design and methods” (2nd ed.), Newbury Park, CA: SAGE Publications. 
Zahra, S.A. (2003), "International expansion of U.S. manufacturing family businesses: The effect of ownership and involvement," Journal of Business Venturing, Vol. 18 No. 4, pp. 495-512. 